Uganda Journal of Agricultural Sciences by National Agricultural Research Organisation is licensed under a Creative Commons Attribution 4.0 International License.

Based on a work at www.ajol.info

\title{
Utilisation and conservation status of indigenous woody plant species in a sedentary pastoral production system in south-western Uganda
}

\author{
D. Nabasumba ${ }^{1}$, G. Eilu ${ }^{2}$ J. Bahati ${ }^{2}$ and G. Katwesigye ${ }^{3}$ \\ ${ }^{1}$ Department of Natural Resources Management, Mbarara Zonal Agricultural Research and \\ Development Institute P. O. Box 389, Mbarara, Uganda \\ ${ }^{2}$ Makerere University, School of Forestry, Environment and Geographical Sciences, \\ P. O. Box 7062, Kampala, Uganda \\ 3National Agricultural Advisory Services, P. O. Box 25235, Kampala, Uganda
}

Author for correspondence: buyinzadina@gmail.com

\begin{abstract}
Indigenous woody plant species play a significant role in sustaining pastoral production systems in sub-Saharan Africa. Outside protected areas in Uganda, populations of useful naturally growing woody species are threatened with extinction. Moreover, little is known about the population structure of woody plant species in such unprotected sites to guide conservation strategies. The objective of this study was to identify indigenous woody plant species utilised by the pastoralists in the dry lands of south western Uganda and assess the population structure of the species utilized. A survey involving 100 households was conducted to inventorise woody plants in 55 nested plots of $50 \mathrm{~m} \times 50 \mathrm{~m}$. A total of 70 indigenous woody plant species were utilised by the pastoralists to serve nine purposes. High utilisation of the plant species was in the order of medicine for humans and livestock, firewood, fodder, timber, poles, shade, food and least in crafts. The major woody plant species utilised included Vernonia ammygdalina, Acacia sieberriana, Acacia hockii, Carissa edulis and Albizia coriaria. Allophylus sp was valuable for all the nine purposes, though particularly for human medicine and poles. In terms of conservation status, trees conformed to inverse $J$ shape and bimodal patterns of population structure, indicating current sustainable conservation in some species and an imbalance in species with a bimodal pattern. Most shrubs reflected irregular population structure indicative of unsustainable conservation status. Seedlings for both trees and shrubs were in the low level of abundance, according to Braun- Blanquette cover scale. Sustainable conservation of indigenous woody plant species in a sedentary pastoral system requires aided regeneration
\end{abstract}


that involves supplementing natural regeneration with similar plant species, as well as zoning sites with high woody species diversity. Promotion of community based conservation platforms where pastoralists can be trained on sustainable plant conservation is recommended.

Key words: Population structure, Vernonia ammygdalina, woody plants

\section{Introduction}

Indigenous woody plant species play a major role in sustaining the livelihoods of pastoralists in the dry lands of sub-Sahan Africa. They provide a wide range of products and ecosystem services, and are regarded as vital components of sustainable pastoral production systems (Sinare and Line, 2015). Indigenous woody plant species are utilised variably by pastoralists across locations, as dictated by livelihood strategies (Balehegn et al., 2015). However, outside protected areas in Uganda, pastoralism production lands constitute part of the increasingly important human inhabited areas, where populations of useful naturally growing woody species are threatened with extinction (Tabuti, 2007). Moreover, little is known about the population structure of woody species in such unprotected sites to guide conservation strategies.

Traditionally, pastoralism production systems were sustained through nomadism (Wurzinger et al., 2008), a practice where pastoralists moved through pre-determined routes with their cattle, in search of water and pasture. Gidske et al. (2014) reported that woody plants serve as livelihood security for the survival of people and livestock during the long dry seasons. Seasonal migration of pastoralists ensures that sustainable utilisation of indigenous woody species for socioeconomic and ecosystem functioning is achieved. The time lag of no active pastoralism in a particular area promotes natural regeneration of woody species in previously utilised land and sustainable conservation of indigenous woody plant species are enhanced (Flintan et al., 2013).

However, sedentary pastoralism where pastoralists keep considerable herds of cattle in a defined area and on permanent basis (Hansen et al., 2012), is gradually replacing the traditional nomadic pastoralism in sub-Saharan Africa. Roba et al. (2013) reported that this change in livestock production practices has adversely affected the conservation of woody species in the wild, but the magnitude is unclear thus necessitating investigation. Information on population structure of plants which reflect diameter size class distributions is useful in giving insights on the probability of survival of indigenous woody plant species in a particular habitat and ascertain conservation status (Mekonen et al., 2015).

Woody plant species display four patterns of population structure, including interrupted inverse J shape, J shape, Bell shape and Irregular pattern (Mekonen et al., 2015). The type of population structure displayed by woody plants reflects the action of biotic and abiotic factors that a population has been exposed to in the past and therefore conservation status.

This study assessed the indigenous woody plant species utilised by pastoralists of south western Uganda and their population structure patterns. The information generated will be useful in 
enhancing sustainable conservation of indigenous woody plant species in sedentary pastoral production systems.

\section{MATERIALS AND METHODS}

\section{Study site}

The study was conducted in Ankole ranching scheme (in four sub-counties), located in Nyabushozi County, Kiruhura district $\left(00^{\circ} 12 \times \mathrm{S}, 31^{\circ} 00 \times \mathrm{E}\right)$ in southwestern Uganda, during September to October, 2013. Kiruhura district lies in the cattle corridor belt of Uganda. Ranch 48b

The climate of this belt is semi-arid, with average annual rainfall of $1000 \mathrm{~mm}$ (Kansiime et al., 2014), distributed in a bimodal pattern. Temperatures range between $20^{\circ}$ and $30^{\circ} \mathrm{C}$, with peaks in July. The altitudinal range of the district is 1250 $-1525 \mathrm{~m}$ above sea level. The vegetation is dominated by savannah grassland with scattered trees typical of semi-arid areas. Livestock production is the main livelihood support activity, characterised by ranching in extensively grazed transhumant herds of cattle and goats in a sedentary practice. The human population of Kiruhura district is 14,000 people (UBOS, 2012).

\section{Indigenous woody plant species utilised} by pastoralists

Data of indigenous woody species used by pastoralists were collected through a cross-sectional survey of 100 households in the Ankole Ranching Scheme. Households were selected using simple random sampling techniques (Kotrlik and Higgins, 2001) and over $10 \%$ of the households benefiting from the scheme were interviewed. Data were collected on the names of indigenous woody plant species utilised in their livelihoods and the purposes for which they were utilised.

\section{Population structure of indigenous} woody plant species

The population structure of indigenous woody species utilised by pastoralists was assessed in 11 ranches selected using simple random techniques in the subcounties of Kikatsi, Kenshunga, Nyakashashara and Sanga. Using measuring tapes of 100 meter length, nested plots of $50 \mathrm{~m} \times 50 \mathrm{~m}$ were established 100 meters away from the edge of every ranch, along a transect of approximately 1 kilometer. Each plot was divided into smaller plots of $25 \mathrm{~m}$ x $25 \mathrm{~m}$ and $10 \mathrm{~m} \times 10 \mathrm{~m}$. Diameter at breast height (DBH) of woody plants was determined. Trees ( $>20 \mathrm{~cm} \mathrm{DBH})$ and poles $(10-19.9$ $\mathrm{cm} \mathrm{DBH})$ were assessed in the entire plot of $50 \mathrm{~m}$ x $50 \mathrm{~m}$. Saplings $(5.5-9.9 \mathrm{~cm}$ DBH) were assessed in a smaller plot of $25 \mathrm{~m} \mathrm{x} 25 \mathrm{~m}$; while seedlings (d" $30 \mathrm{~cm}$ height) were assessed in a sub plot of 10 m x $10 \mathrm{~m}$ (Cole et al., 2012). The first plot was selected randomly by allocating and picking a number indicating a side of a transect line. Subsequent plots were established 50 meters apart, in an alternate pattern along a transect line laid in the longest direction in each ranch. Up to 5\% of every ranch was assessed and a total of 55 plots representing 13.75 hectares were covered. Seedlings were evaluated based on the principles of vegetation cover analysis by Braun-Blanquette (Westhoff and Van Der Maarel, 1980). This method enables quick evaluation of small classes of vegetation by using area cover scales. Usually, a scale of $1-5$ is used where 1 represents $1-20 \%$ species area cover, $2=$ $21-40 \%, 3=41-60 \%, 4=61-80 \%, 5=81$ $100 \%$.

Preliminary identification of woody plants was done by key informants who gave the local names of the species. 
However, specimens of each species encountered were collected, pressed in paper materials and delivered to Makerere University herbarium for confirmation.

\section{Data analysis}

The data collected were entered in SPSS.16.0 and Microsoft Excel computer packages for processing. Descriptive statistics were used to generate frequency tables and population structure graphs. The population of seedlings was subjected to Braun-Blanquette scale to determine the area cover scales.

\section{RESULTS}

Indigenous woody plant species utilised by pastoralists

A total of 70 indigenous woody plant species (40 shrubs and 30 trees) occurring in 31 plant families was utilised by the pastoralists to serve nine purposes (Table $1 \mathrm{~s})$. The uses included food, fodder, human medicine, animal medicine, fuel wood, poles, timber, crafts materials and provision of shade (Table 1). High utilisation of the species was in the order; medicine for humans and livestock, firewood, fodder, timber, poles, shade, food and least in crafts (Fig. 1).

Most indigenous woody plant species were described as multipurpose to pastoralists. However, Allopyhlus sp. was identified to be valuable for all the nine purposes reported (Table 1). This was followed by Ficus natalensis and Nuxius congesta, which were utilised for eight purposes. Species Microglossa pyrifolia, Bosci coriaceae, Astripomoe amalvaceae, indigofera emerginella, macrotyloma axillare, Myrica kandtiana, Boerhavia diffusa, had the lowest level of utilisation whereby only one purpose of utilisation was reported.
The purpose for which such species were utilised was source of medicine either to human or livestock (Table 1).

Vernonia ammygdalina dominated the species used for human and animal medicine (Table 2). Several species were used for firewood (40 species) with Acacia sieberriana being the dominant (Table 2). For other purposes, Acacia hockii, Albizia coriaria Carissa edulis and Grewia kakothamnos dominated species utilised for fodder, timber, food and crafts, respectively. Albizia coriaria was as well found to be useful in providing shade in the grazing grounds. Although $14 \%$ of the species were reported to be utilised for food purposes, $99 \%$ of the respondents utilised the species to obtain fruits and nuts (Table 2).

\section{Population structure of indigenous woody plant species}

Plant inventory for assessing plant population structure recorded 39 indigenous woody plant species comprising 22 shrubs and 17 trees, in 55 plots covering 13.75 ha. The woody plant species recorded in the plant inventory displayed three types of plant population structure and these were Inverse $\mathrm{J}$ shape, bimodal and irregular shape patterns.

Trees displayed the Inverse $\mathbf{J}$ shape and bimodal patterns of population structure. The inverse $\mathbf{J}$ shape pattern for trees was constituted by Acacia hockii, Grewia mollis. Allophylus sp and Teclea nobilis; while the bimodal pattern was constituted by Acacia gerrardii, Jasminum pauciflorum, Acacia persiciflora and Euphorbia candelabrum (Figs. 2a and b.). Shrubs, on the other hand, displayed the inverse $\mathbf{J}$ shape and irregular patterns of plant population structure. The inverse $\mathrm{J}$ shape of shrubs was constituted by Rhus 
Table 1. Top 20 indigenous woody plant species used by pastoralists of south-western Uganda

\begin{tabular}{|c|c|c|c|c|c|c|c|c|c|c|c|c|}
\hline \multirow[t]{2}{*}{ Family } & \multirow[t]{2}{*}{ Species (Scientific name) } & \multirow[t]{2}{*}{ Local name } & \multicolumn{10}{|c|}{ Responses for uses of species from 100 households } \\
\hline & & & Food & Fodder & $\begin{array}{c}\text { Human } \\
\text { medicine }\end{array}$ & $\begin{array}{r}\text { Animal } \\
\text { medicine }\end{array}$ & $\begin{array}{l}\text { Fire } \\
\text { wood }\end{array}$ & Poles & Timber & Shade & Crafts & $\begin{array}{l}\text { Cumulative } \\
\text { frequency } \\
\text { of } \\
\text { responses }\end{array}$ \\
\hline \multirow[t]{3}{*}{ Fabaceae } & Albizia coriaria Oliv. & Omusisa & 0 & 37 & 59 & 58 & 73 & 77 & 79 & 24 & 0 & 407 \\
\hline & Acacia sieberiana $D C$. & Omutyaza & 0 & 46 & 40 & 41 & 77 & 69 & 55 & 15 & 0 & 343 \\
\hline & Acacia gerrardii Benth. & Omutongole & 0 & 42 & 39 & 42 & 74 & 68 & 44 & 8 & 0 & 317 \\
\hline Anacardiaceae & Rhus natalensis Bernh. ex Krauss & Omusheshe & 84 & 70 & 47 & 35 & 37 & 28 & 12 & 0 & 0 & 313 \\
\hline Fabaceae & Acacia hockii De Wild. & Orugando & 0 & 73 & 40 & 46 & 62 & 37 & 24 & 0 & 0 & 282 \\
\hline Sapindaceae & Allophylus $S p$ & Omutete & 24 & 45 & 46 & 41 & 45 & 46 & 21 & 3 & 1 & 272 \\
\hline Tiliaceae & Grewia mollis Juss. & Omukoma & 0 & 60 & 19 & 25 & 46 & 44 & 29 & 3 & 0 & 226 \\
\hline Asteraceae & Vernonia amygdalina Delile & Omubirizi & 0 & 57 & 78 & 71 & 11 & 0 & 0 & 0 & 0 & 217 \\
\hline Apocynaceae & Carissa edulis (Forssk.) Vahl & Omuyonza & 99 & 28 & 23 & 13 & 5 & 0 & 0 & 0 & 0 & 168 \\
\hline Moraceae & Ficus natalensis Krauss ex Engl. & Omutooma & 0 & 24 & 15 & 23 & 33 & 30 & 27 & 6 & 2 & 160 \\
\hline Fabaceae & Erythrina abyssinica $D C$ & Ekiko & 0 & 0 & 33 & 23 & 37 & 36 & 15 & 1 & 1 & 146 \\
\hline Ulmaceae & Scutia myrtina (Burm. f.) Kurz & Omugasha & 81 & 15 & 13 & 9 & 18 & 1 & 5 & 0 & 0 & 142 \\
\hline Verbanaceae & Lantana trifolia $L$ & Ehuuki & 71 & 4 & 33 & 31 & 3 & 0 & 0 & 0 & 0 & 142 \\
\hline Celastraceae & Maytenus senegalensis (Lam.) Exell & Omunyabiruko & 0 & 11 & 42 & 42 & 17 & 15 & 4 & 0 & 0 & 131 \\
\hline Capparaceae & Maerua triphylla A. Rich. & Omwoyante & 0 & 64 & 23 & 24 & 6 & 2 & 2 & 0 & 0 & 121 \\
\hline \multirow[t]{2}{*}{ Euphorbeaceae } & Flueggea virosa (Roxb. ex Willd.) Royle & Omubwera & 0 & 13 & 34 & 30 & 10 & 8 & 3 & 0 & 0 & 98 \\
\hline & $\begin{array}{l}\text { Euphorbia candelabrum Tremaux ex } \\
\text { Kotschy }\end{array}$ & Enkukulu & 0 & 0 & 46 & 29 & 7 & 5 & 2 & 0 & 0 & 89 \\
\hline Ebeneaceae & Euclea latidens Stapf & Omusikizi & 0 & 5 & 18 & 21 & 17 & 15 & 8 & 0 & 0 & 84 \\
\hline Solanaceae & Capsicum frutescens $L$ & Esheka & 54 & 2 & 15 & 6 & 3 & 0 & 0 & 0 & 0 & 80 \\
\hline Fabaceae & Erythrophleum pyrifolia & Omurama & 0 & 4 & 18 & 16 & 18 & 14 & 4 & 3 & 0 & 77 \\
\hline
\end{tabular}




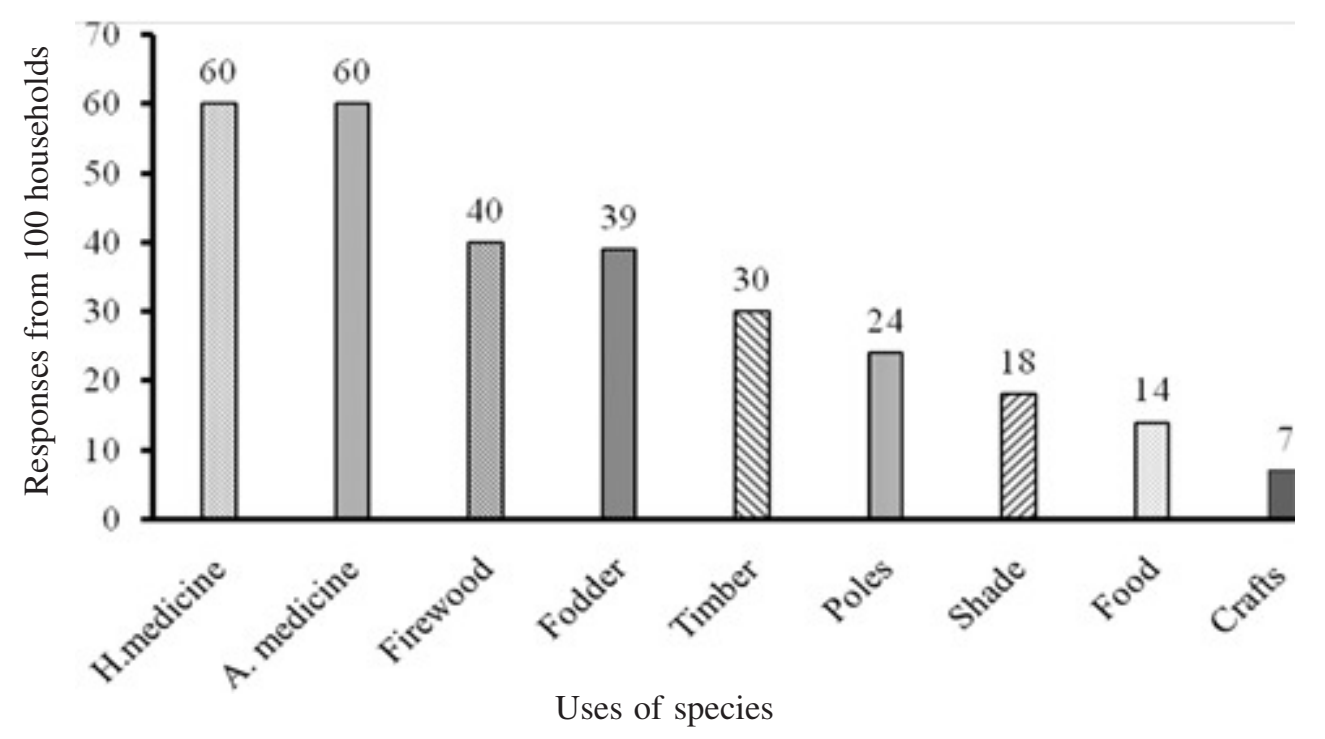

Figure 1. Utilisation of indigenous woody plant species in the pastoralist systems of southwestern Uganda.

Table 2. Major indigenous woody species used for different purposes in the pastoralist systems of south-western Uganda

\begin{tabular}{lllc}
\hline Purpose & $\begin{array}{l}\text { Major woody species } \\
\text { utilised }\end{array}$ & Family & $\begin{array}{c}\text { Frequency of responses } \\
\text { (N=100 households) }\end{array}$ \\
\hline Food & Carissa edulis & Apocynaceae & 99 \\
Timber & Albizia coriaria & Fabaceae & 79 \\
Human medicine & Vernonia ammygdalina & Asteraceae & 78 \\
Firewood & Acacia sieberriana & Fabaceae & 77 \\
Fodder & Acacia hockii & Fabaceae & 73 \\
Animal medicine & Vernonia ammygdalina & Asteraceae & 71 \\
Poles & Acacia sieberiana & Fabaceae & 69 \\
Shade & Albizia coriaria & Fabaceae & 24 \\
Crafts & Grewia kakathamnos & Tiliaceae & 3 \\
\hline
\end{tabular}

natalensis and Scutia myrtina; while the irregular pattern was constituted by Hoslundia opposite, Asparagus flagellaris, Carissa macrocarpa, Capparis fascicularis, Clerodendrum myricoides, Duranta erecta., Flueggea virosa., Pluchea ovalis., Lantana. trifolia, Rytigyna macrura and Grewia kakothamnos. (Figs. 3a. and b.).

Among tree species, Albizia coriaria, Albizia glaberrima, Nuxius congesta, Euclea latidens., Erythrina abyssinica., Gardenia sp., Ficus ovata and Croton megalocarpus had low plant populations 


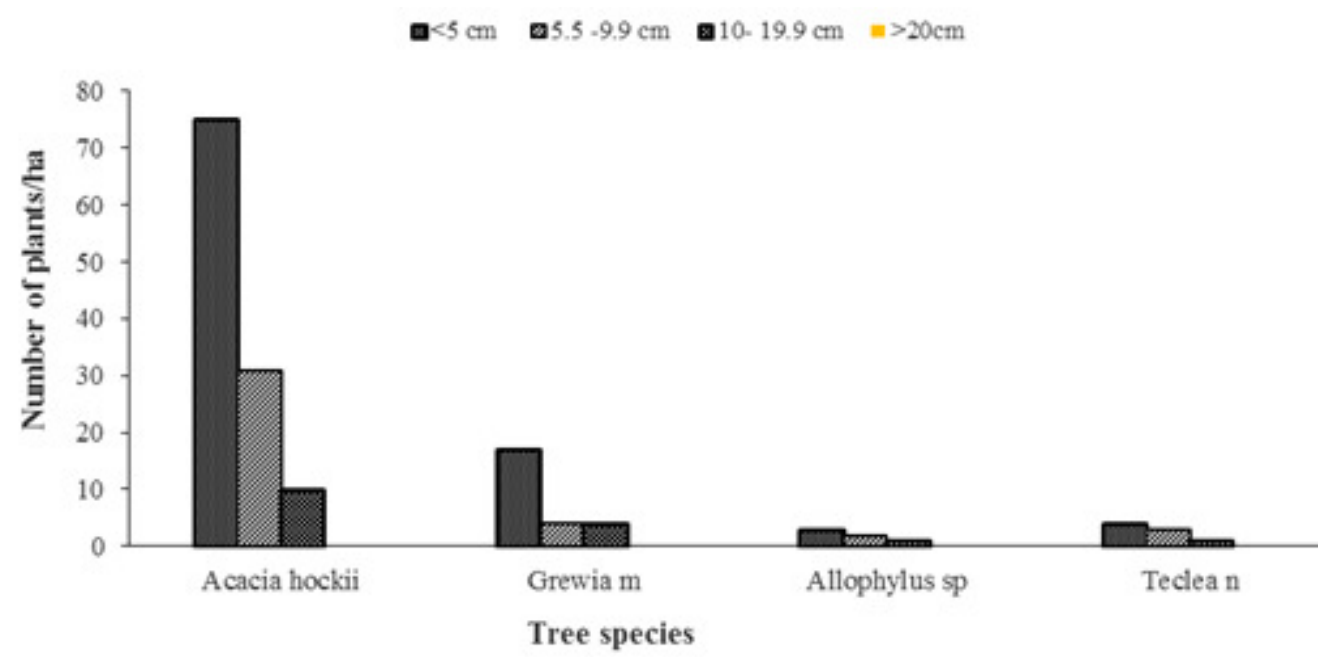

Figure 2a. Inverse J shape population structure of trees in the pastoralist systems of southwestern Uganda.

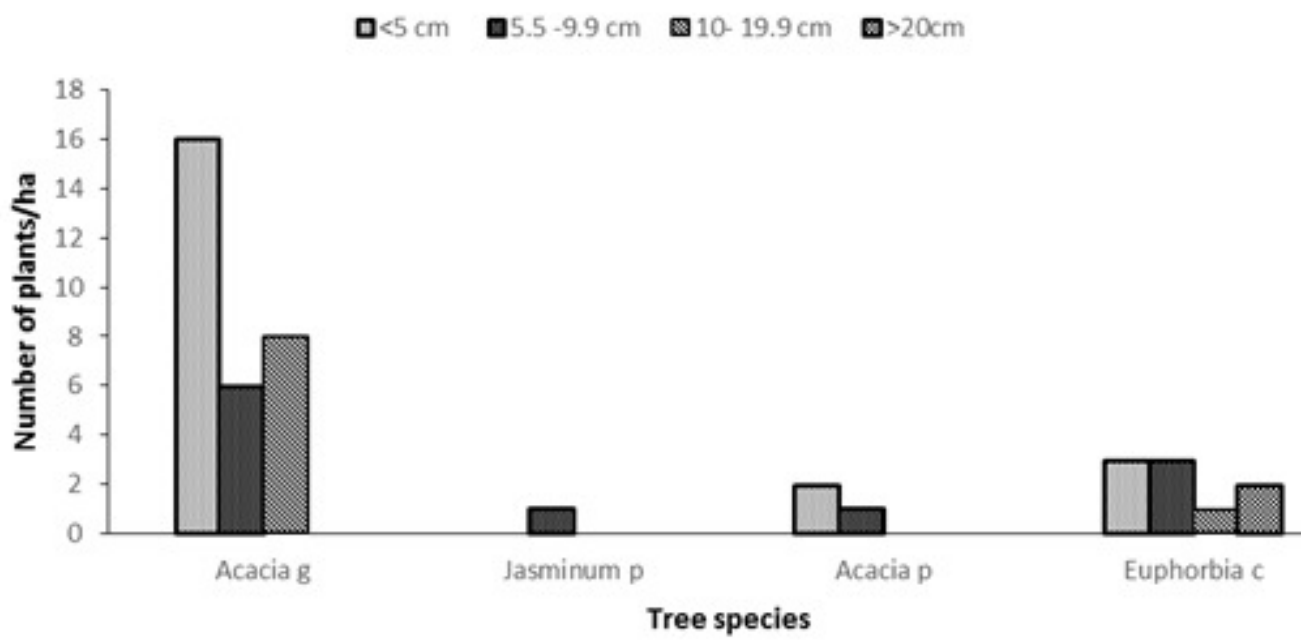

Figure 2b. Bimodal pattern population structure of trees in the pastoralist systems of southwestern Uganda.

per hectare, to generate population structure curves which was the case for Carissa edulis., Microglossa pyrifolia., Solanum renschii., Ehretia cymosa., Maytenus senegalensis, Maytenus heterophylla., Triumfetta rhomboidea and Erythrococca bongensis among shrubs.
Assessment of populations of seedlings using the Braun-Blanquette method revealed that the general pattern for the population of seedlings in trees and shrubs was scale 1 (1-20\%) area cover (Fig. 4). This was mainly composed of Acacia hockii for trees and Asparagus 


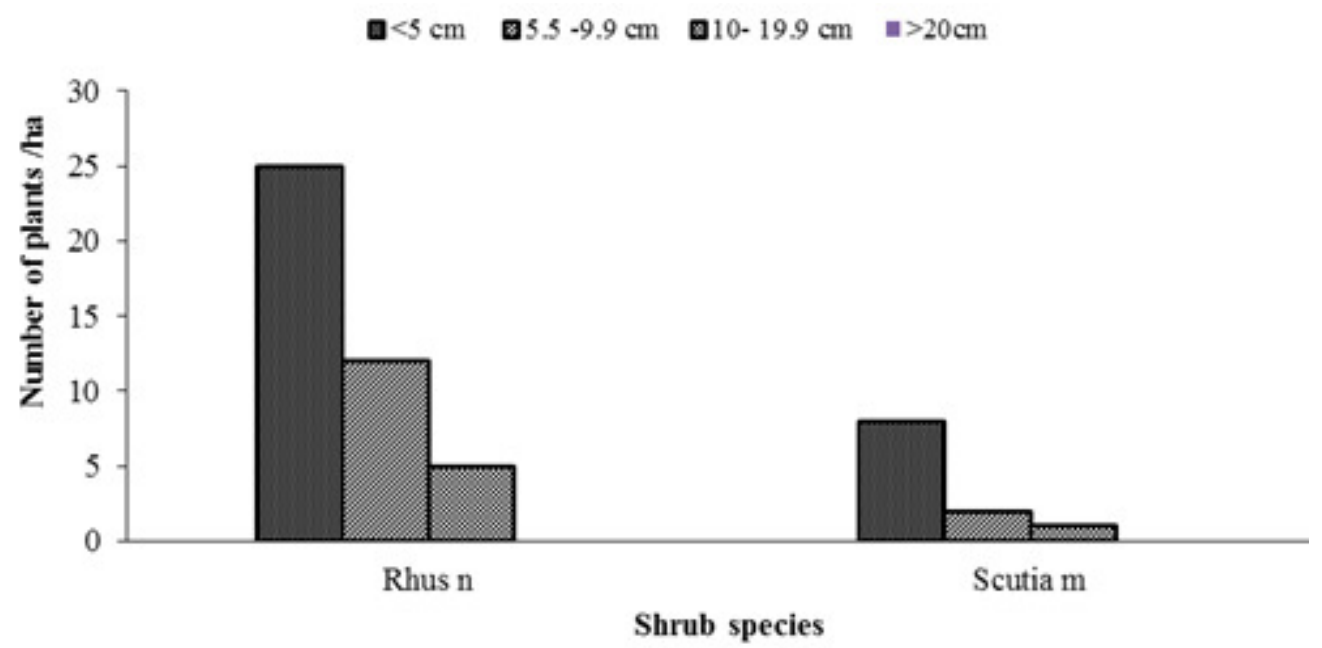

Figure 3a. Inverse J shape population structure of shrubs in the pastoralist systems of southwestern Uganda.

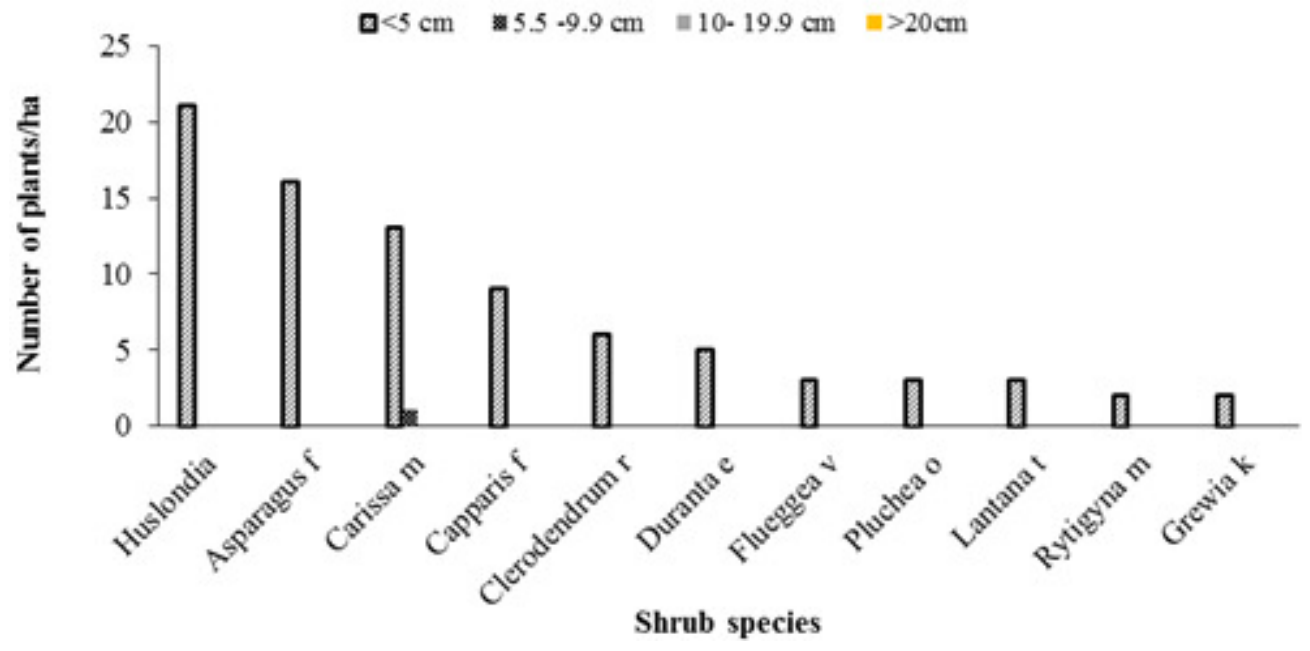

Figure 3b. Irregular shape population structure of shrubs in the pastoralist systems of south-western Uganda. 


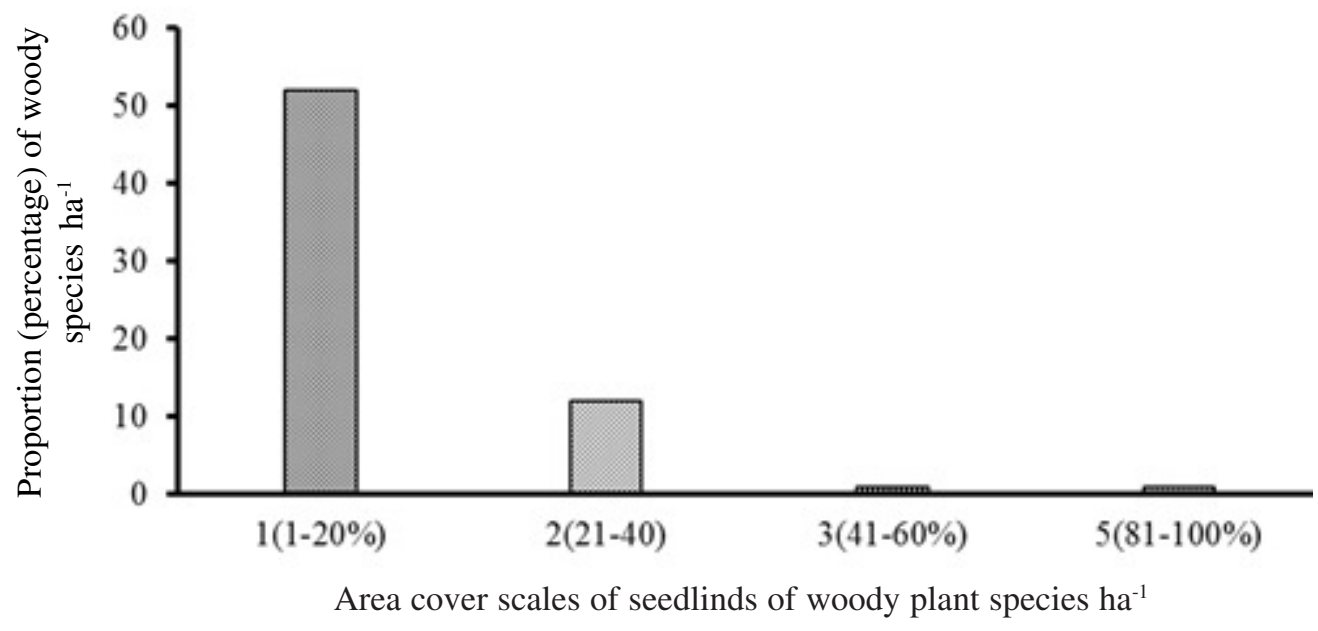

Figure 4. Area cover scales of seedlings of woody plant species per hectare in the pastoralist systems of south-western Uganda according to Braun-Blanquette assessment.

flagellaris, as well as Grewia kakothamnos for shrubs.

\section{Discussion}

Indigenous woody plant species utilised by the pastoralists

Knowledge of indigenous woody plants used by pastoralists and their patterns of utilisation is important in ensuring sustainable conservation of plant species. The 70 indigenous woody plant species recorded in this study (Table 1s.) and the nine different purposes for which they are utilised reflect the significance of indigenous woody plant species in sustaining the livelihoods of pastoralists. High utilisation of the species was in the order; medicine for humans and livestock, firewood, fodder, timber, poles, shade, food and least in crafts. Similar studies on utilisation of indigenous woody plant species in other communities in Uganda revealed a different pattern from the results of this study. A study by Eilu et al. (2007) revealed high utilisation of indigenous plant species in eastern
Uganda in the order of food, medicine, firewood, construction, crafts, environmental services, provision of shade, and cultural purposes. The pattern of use of indigenous woody plant species varies across locations, as dictated by their livelihood strategies (Balehegn et al., 2015). Such patterns may have implications regarding conservation of indigenous woody plant species in unprotected sites stemming from varying degree of species utilisation.

The high responses recorded for utilisation of indigenous woody plants as medicines (Fig. 1.) can be attributed to the role such species play in enhancing proper health care to people and curing livestock diseases (Tolossa et al., 2013). Acceptance of traditional medicine by communities and the difficulty to access modern health care facilities in pastoral communities could be the underlying factors for the observed people-plant relationship. As study by Reynold et al. (2007) revealed that semi-arid areas where pastoralists operate are often isolate, thus limiting access to services. 
The integral role of woody plant species in meeting health care needs provides an important opportunity for enhancing sustainable conservation of these species.

Besides health care needs, the relatively high utilisation of indigenous woody plant species for firewood justifies the current statistics of demand for fuel wood resources (Figure 1). Over 90\% of Uganda's rural population depends on woody biomass for their domestic fuel needs. Unsustainable utilisation of woody plant species for fuel wood, especially for commercial purposes is one of the leading challenges for conservation of plant species outside protected areas (Sassen et al., 2015). Such challenges call for identification of strategies that promote sustainable use of fuel wood resources.

More than half of the major indigenous woody plants documented in this study were reported to be sources of fodder (Table 1). This could be attributed to the scarcity of fodder, especially in the dry season. Woody plants provide supplementary feeds to livestock, especially in the dry season when ground forage is lacking (Teklehaimanot et al., 2007). Retention of woody plants as supplementary feed is therefore, an opportunity to enhance conservation of plant species in a sedentary production system while providing social-economic benefits to pastoralists.

Whereas only $14 \%$ of the species documented were sources of food in form of fruits and nuts (Table 2), most of the species reported had high frequencies of utilisation from the respondents. For instance, Carissa edulis was reported to be a source of food to $99 \%$ of the households interviewed. Accoding to McGarry and Shackleton (2009), such information re-emphasises the importance of indigenous wild woody species as safety nets for food security in pastoralism production systems. Promoting large scale production of such species can increase social economic benefits of the species while enhancing conservation.

\section{Population structure of indigenous woody plant species}

The inverse $\mathbf{J}$ shape displayed in this study by some species of trees and shrubs reflects sustainable conservation status of such species. Mekonen et al. (2015) reports that woody plant species display the Inverse J-shape of population structure when species' frequency distribution has higher frequencies in the lower diameter classes and a gradual decrease towards the higher classes. In such a pattern there are many seedlings that could be recruited into successive growth stages and therefore enhance sustainable conservation of woody plant species. The population structure patterns of woody plant species provide an important indicator of conservation status of plant species. The action of biotic and abiotic factors to which a population is exposed in the past can be predicted from population structure information (Alexandra, 2007).

Besides the inverse $\mathbf{J}$ shape of plant population structure, over $28 \%$ of the indigenous woody plant species displayed an irregular pattern of plant population structure with majority being shrubs (Fig. 3b.). Most of the species which constituted this type of population structure in the study had individuals in the lower diameter size class (seedlings) and few or no individuals in subsequent diameter size classes. When species display this kind of diameter size class distribution, it implies that regeneration is not keeping pace with mortality and disturbance above a fixed diameter limit removes woody 
plants that could be recruited into bigger size classes (Mekonen et al., 2015). This usually happens if a large number of poles and mature individuals are harvested before seed production to sustain recruitment (Mueller et al., 2005). Such observation could as well explain the relatively large number of species with low populations.

Traditionally, survival of indigenous woody species in pastoralism production systems was permitted by the seasonal migration behavior of pastoralists (Alexandra, 2007). The time lag of no active pastoralism in a particular area ensured natural regeneration and recruitment of woody species in a previously utilised land. In the current sedentary pastoralism, the rate of animal turnover on grazing lands is increasing, livestock populations have not only altered the species composition of these areas but also altered the size class distribution of certain species (Zhao et al., 2007). Such secondary data is further confirmed by the low level of seedling abundance according to Braun Blanquette cover scale.

In relation to conservation status of indigenous woody plant species, conformity of Allophylus sp. to the inverse $\mathrm{J}$ shape, which species was reported to be useful for all the nine purposes reported in the household survey results indicate deliberate conservation of the species thus the relatively sustainable conservation status. However, Ficus natalensis and Nuxius congesta which similarly to Allophylus sp. had numerous purposes of utilisation (8 purposes) had low individual populations, which depicts unsustainable conservation. Social economic and ecological factors underlying conservation of species which conformed to the inverse $\mathrm{J}$ shape need to be explored. These will give insights for sustainable conservation of other woody plant species which displayed a bimodal and irregular patterns of plant population structure as well as species which had low populations to generate population structure graphs.

\section{Conclusion}

This study documented a total of 70 indigenous woody plant species utilised by the pastoralists of south western Uganda. Although the major purposes for which the species were utilised was provision of medicine to human and livestock, the plant species were also used to provide firewood, fodder, timber, poles, shade, food and least in crafts. Allophylus sp. is found to be useful for all the nine purposes documented. Three types of plant population structure patterns are identified, where most of the trees conform to the Inverse $\mathrm{J}$ shape and bimodal patterns; while the shrubs mostly conform to the irregular pattern. The general trend of plant population structure observed does not suggest sustainable conservation status. Sustainable conservation of indigenous woody plant species in a sedentary pastoral system requires aided regeneration that involves supplementing natural regeneration with similar plant species. Further research is needed on propagation pathways of major species to aid regeneration. Zoning of sites with high woody species diversity as well as promotion of community based conservation platforms where pastoralists can be trained on sustainable plant conservation is recommended. 


\section{Acknowledgement}

Thanks go to National Agricultural Research Organization of Uganda for funding this study. Farmers of Ankole Ranching Scheme are highly appreciated for providing research information and granting access to the study sites.

\section{References}

Alexandra, S.F. 2007. Ecological interpretation and population structure sizes in trees: The case of Araucariaa angusitifolia in S. America. Austral Ecology 32:524-533.

Balehegn, M., Eik, L.O. and Tesfay, Y. 2015. There is more in fodder trees than their nutritional values: local valuation of indigenous fodder trees and shrubs by pastoral and agrarian communities in northern Ethiopia. Forests, Trees and Livelihoods 24 (2): 112-127.

Eilu, G., Oriekot, J. and Tushabe, H. 2007. Conservation of indigenous plants outside protected areas in Tororo District, eastern Uganda. African Journal of Ecology 45 (s3): 73-78.

Gidske, L. A., Krzywinski, K., Talib, M., Saadallah, A. E., Hobbs, J.J. and Pierce R.H. 2014. Traditional nomadic tending of trees in the Red Sea Hills. Journal of Arid Environments 106: 36-44.

Hansen, A. J., DeFries, R. S. and Turner, W. 2012. Land use change and biodiversity. In land change science. pp. 277-299. Springer Netherlands.

Kansiime, C., Mugisha, A., Makumbi, F., Mugisha, S., Rwego, L.B., Sempa, J. and Rutebemberwa, E. 2014. Knowledge and perceptions of brucellosis in the pastoral communities adjacent to Lake Mburo National Park, Uganda. BMC Public Health 14 (1).
Kotrlik, J. W. K. J. W. and Higgins, C. C. H.C.C. 2001. Organizational research: Determining appropriate sample size in survey research appropriate sample size in survey research. Information Technology, Learning, and Performance Journal 19 (1): 43.

McGarry, D.K. and Shackleton, C.M. 2009. Children navigating rural poverty: Rural children's use of wild resources to counteract food insecurity in the Eastern Cape, South Africa. Journal of Children and Poverty 15(1): 1937.

Mekonen, T., Ayele, B. and Ashagrie, Y. 2015. Woody plant species diversity, structure and regeneration status of Woynwuha Natural Forest, North west Ethiopia. Asian Journal of Ethnopharmacology and Medicinal Foods 3.

Mueller, R. C., Scudder, C. M., Porter, M. E., Talbot Trotter, R., Gehring, C. A. and Whitham, T. G.2005. Differential tree mortality in response to severe drought: Evidence for long term vegetation shifts. Journal of Ecology 93(6): 1085-1093.

Sassen, M., Sheil, D. and Giller, K. E. 2015. Fuel wood collection and its impacts on a protected tropical mountain forest in Uganda. Forest Ecology and Management 354: 5667.

Sinare, H. and Line, J. G. 2015. Ecosystem services from woody vegetation on agricultural lands in Sudano-Sahelian West Africa .Agriculture, Ecosystems and Environment 200: 186-199.

Reynold, J.f., Stafford, D.M.S., Lambin, E.F., Tuner, II. B. L., Mortimore, M., Batterbury, S. P. J., Downing T. E., Dowlatabadi, H., Fernandez, R. J., Herrick, J.E., Sannwald, E.H.Jiang H., Leemans, R., Lynam, T., Maestre, F., 
Ayarza, M. and Walker, B. 2007. Global desertification: Building science for dry land development. Science 316 (5826): 847-851.

Roba, H.G. and Oba, G. 2013. Understanding the role of local management in vegetation recovery around pastoral settlements in northern Kenya. Environmental Management 51 (4): 838-849.

Tabuti J.R. 2007. The uses, local perceptions and ecological status of 16 woody species of Gadumire Subcounty, Uganda. Biodiversity and Conservation 16 (6): 1901-1915.

Teklehaimanot, Z., Akinnifesi, F. K., Leakey, R. R. B., Ajaui, O. C., Sileshi, G., Tchoundjeu, Z. and Kwesiga, F. R. 2007. The role of indigenous fruit trees in sustainable dryland agriculture in Eastern Africa. In: Leakey, R.R.B, and Ajayi, C.O. (2008). (eds.). Indigenous Fruit Trees in the Tropics: Domestication, Utilization and Commercialization, CAB, UK. 429.

Tolossa, K., Debela, E., Athanasiadou, S., Tolera, A., Ganga, G. and Houdijk, J. G. 2013. Ethno-medicinal study of plants used for treatment of human and livestock ailments by traditional healers in South Omo, Southern Ethiopia. Journal of Ethnobiology and Ethnomedicine 9(1): 1.

Uganda Bureau of Statistics (UBOS) and ICF International Inc. 2012. Uganda Demographic and Health Survey 2011. Kampala, Uganda: UBOS and Calverton, Maryland: ICF International Inc.

Westhoff, V. and Van Der Maarel, E. 1980. The Braun-Blanquet approach: In: Whittaker, R.H. (ed.), Classification of plant communities, Junk: The Hague.

Wurzinger, M., Ndumu, D., Okayo, A.M. and Solkner, J. 2008. Lifestyle and herding practices of Bahima pastoralists in Uganda. African Journal of Agricultural Research 3 (8): $542-548$.

Zhao, W.Y., Li, J. L. and Qi, J.G. 2007. Changes in vegetation diversity and structure in response to heavy grazing pressure in the northern Tianshan Mountains, China. Journal of Arid Environments 68 (3): 465 - 479. 